\title{
Assessment of Environmental Impacts of Limestone Quarrying Operations in Thailand
}

\author{
Suthirat KITTIPONGVISES ${ }^{1-3 *}$ \\ ${ }^{1}$ Environmental Research Institute, Chulalongkorn University (ERIC), Bangkok 10330, Thailand \\ ${ }^{2}$ Research Program of Toxic Substance Management in the Mining Industry, \\ Center of Excellence on Hazardous Substance Management (HSM), Bangkok 10330, Thailand \\ ${ }^{3}$ Research Unit of Green Mining Management (GMM), \\ Chulalongkorn University, Bangkok 10330, Thailand
}

\begin{abstract}
Environmental impacts of the mineral extraction have been a public concern. Presently, there is widespread global interest in the area of mining and its sustainability that focused on the need to shift mining industry to a more sustainable framework. The aim of this study was to systematically assess all possible environmental and climate change related impacts of the limestone quarrying operation in Thailand. By considering the life cycle assessment method, the production processes were divided into three phases: raw material extraction, transportation, and comminution. Both IMPACT 2002+ and the Greenhouse Gas Protocol methods were used. Results of IMPACT 2002+ analysis showed that per 1 ton crushed limestone rock production, the total depletion of resource and GHGs emissions were $79.6 \mathrm{MJ}$ and $2.76 \mathrm{~kg} \mathrm{CO} 2$ eq., respectively. Regarding to the four damage categories, 'resources' and 'climate change' categories were the two greatest environmental impacts of the limestone rock production. Diesel fuel and electricity consumption in the mining processes were the main causes of those impacts. For climate change, the unit of $\mathrm{CO}_{2}$ eq. was expressed to quantify the total GHGs emissions. Estimated result was about $3.13 \mathrm{~kg} \mathrm{CO} 2 \mathrm{eq}$. per ton limestone rock product. The results obtained by the Greenhouse Gas Protocol were also similar to IMPACT 2002+ method. Electrical energy consumption was considered as the main driver of GHGs, accounting for approximately $46.8 \%$ of total fossil fuel $\mathrm{CO}_{2}$ emissions. A final point should be noted that data uncertainties in environmental assessment over the complete life cycle of limestone quarrying operation have to be carefully considered.
\end{abstract}

Keywords - Climate change; carbon dioxide $\left(\mathrm{CO}_{2}\right)$ emissions; environmental impacts; GHG protocol; IMPACT 2002+; limestone mining; life cycle impact assessment (LCA)

\section{INTRODUCTION}

The environmental problems facing mankind in the 21st century are global climate change, natural resources depletion and also ecosystem degradation [1]. Crucially, climate change is recognized as one of the greatest long-term threat facing global society. All regions of the world have experienced a notable increase in average temperature over time. As a historic year, the earth's 2015 surface temperature was the warmest year since 1880 [2]. The global combined land and ocean surface temperature has also increased by about 0.85 [0.65 to 1.06$]{ }^{\circ} \mathrm{C}$ from 1880 to 2012 [3]. It is virtually certain that the observed global warming from human-produced greenhouse gases (GHGs) has been the primary cause of climate change. Evidently, anthropogenic GHGs emissions have risen since the late 19th century, with an increase about $35 \%$ from 1990 to 2010 [4]. The need to accelerate efforts to lower the emissions of GHGs is therefore becoming

\footnotetext{
* Corresponding author.

E-mail address: suthirat.k@chula.ac.th
} 
urgent. On the global scale, in 2010, industrial sector accounted for approximately $21 \%$ of total emissions [5]. Emissions from this sector include chemical, metallurgical and mineral production. Manufacturing that includes production of all products, such as cement, iron and steel, pulp and paper, textiles, was responsible for approximately $98 \%$ of total direct $\mathrm{CO}_{2}$ emissions from the industrial sector [6]. The production of non-metallic mineral, especially cement, iron and steel, results in $44 \%$ of all $\mathrm{CO}_{2}$ emissions. Industry-related GHGs emissions are also crucially dominated by the Asia region (52\% in 2010) [6]. In Thailand, according to the first biennial report under the United Nations Framework Convention on Climate Change [7], total national GHGs emissions in 2011 were about 305.52 million ton of $\mathrm{CO}_{2}$. Energy sector accounted for the largest share of emissions $(72.79 \%)$, followed by agriculture and industry, respectively. Within the industrial sector, mineral production was by far the largest and accounted for nearly $98 \%$ of total GHGs emissions (Fig. 1). The possible sources of emissions are fuel and electricity consumed by machinery in both extraction and mineral processing. In terms of economic contribution, industrial sector plays in critical role in driving the national economy (34\% of total GDP in 2011). Among these, mineral and mining industry contributed for about $5 \%$ of total GDP [8]. Within this, as presented in Fig. 2, limestone was the largest share of mineral demand in Thailand, followed by lignite, basalt, granite and shale, respectively. More specifically, most of mined products in Thailand were used as an industrial rock construction [9].

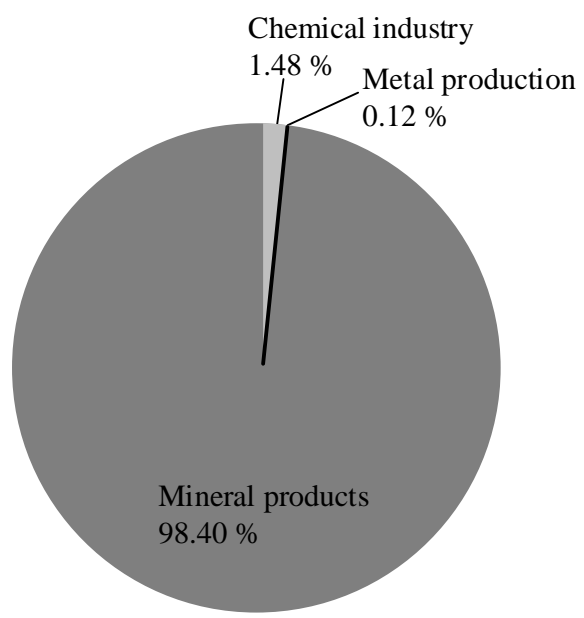

Fig. 1. GHGs emissions from the industrial sector in Thailand in 2011, $18.23 \mathrm{Mt} \mathrm{CO}_{2}$ eq. [7]. 


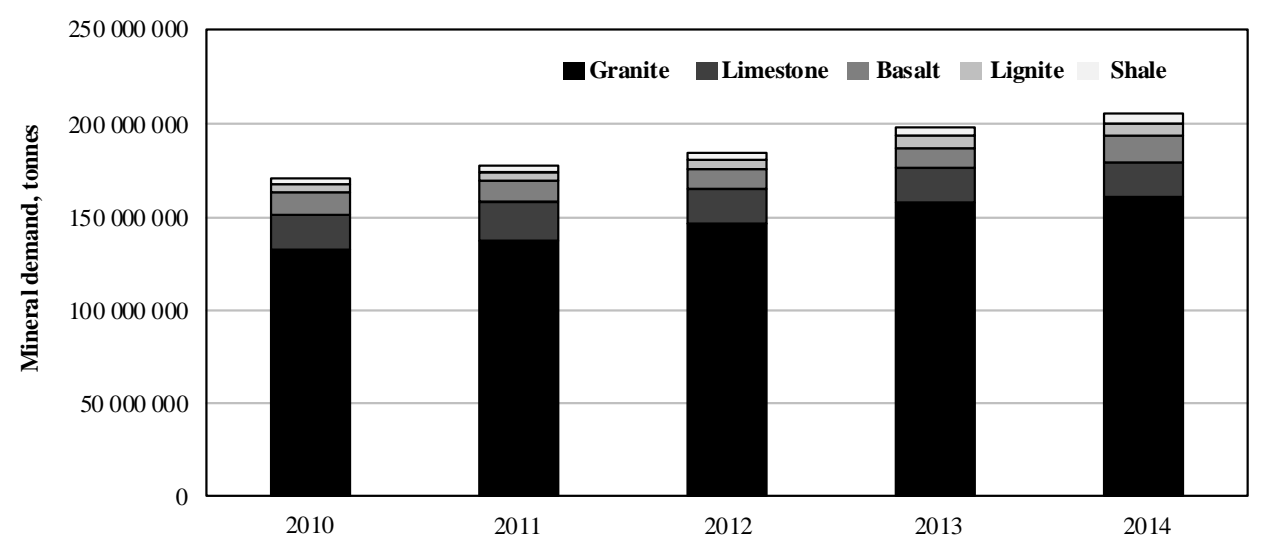

Fig. 2. Mineral resources demand in Thailand, 2010-2014 [9].

Despite the growing importance of mineral extraction and mining production, there has been an increasing concern over environmental impacts associated with the exploration, extraction and use of mineral product [10]-[13], and this makes environmental sustainability in the mining industry crucial (i.e. social, economic and environmental dimensions). For instance, environmental impacts of the coal mining and processing include destruction of forests and ecosystems, acid mine drainage and contaminant, acidification, water pollution, resource intensity and also climate change impacts [14]. Further, it has been pointed out previously by Norgate [15] that energy and GHGs impacts of mineral and mining operations will become much more significant in the future society than they presently are. For that reason, there has been increased discussion and global attention on the sustainability of mining and mineral productions. Mineral extraction, in other words, is an industry placed into intersection of all environmental, economic and social dimensions [16], [17]. More specifically, regarding to the Sustainable Development Goal 13 [18], to combat climate change and its impacts, mining and mineral industry can contribute to a solution by engaging with key stakeholders to enhance their adaptive capacity and also by lowering their carbon footprint. In the context of Thailand, government has also launched the policy on "Green Mining" in 2009 aimed to encourage mining entrepreneurs to go 'green' by the following principles:

- Environmental and social responsibility;

- Pollution prevention and reduction of the environmental impacts;

- Keeping all stakeholders safe and healthy during mineral and mining operations;

- Operating mining areas are clean and green;

- Transparency and accountability;

- Enhancing efficient of mineral resources with the aim of achieving sustainable development in the mining and mineral industry [19].

This could mean that the management approach may involve developing new environmental performance evaluation tools for the mining industry to more understand about the negative impacts of their production processes. There are a number of different tools used for investigating the environmental performance of the mining operations, such as Environmental Impact Assessment, Ecological Risk Assessment, Ecological Footprint, GHGs Footprint [11], [20], Material Flow Analysis, and Life Cycle Assessment (LCA) [14], [21]. 
The concept of LCA has, in its turn, sparked worldwide interest in assessing the environmental performance of a product or service (also known as life cycle analysis or cradle-to-grave approach). Several studies employing LCA framework to assess all related environmental impacts of the production have been identified by focusing on its principles and covering LCA framework for food [22], energy sources such as bioenergy [23], [24], solar [25], [26] and wind energy [27], [28], materials [29], and building and construction [30]-[34]. For the mineral processing, LCA practitioners have been seeking to explore the answer of how mining can become more environmentally sustainable for many years. Such applications include iron ore mining [35], coal [36], [37], copper [38], [39], aluminum [40], and gold production [41]. Norgate [11] also assessed all environmental impacts of the gold extraction and production with regards to GHG emissions $\left(\mathrm{t} \mathrm{CO}_{2}\right.$ eq./t $\left.\mathrm{Au}\right)$, embodied energy $(\mathrm{GJ} / \mathrm{t} \mathrm{Au})$, embodied water $(\mathrm{t} / \mathrm{t} \mathrm{Au})$ and solid waste burden $(\mathrm{t} / \mathrm{t} \mathrm{Au})$ by using LCA method. In the climate change field, a cradle-to-gate LCA of uranium, gold and copper mining in Australia was performed to investigate all potential sources of GHGs in the mining industries in Australia (i.e. emissions associated with mining and milling operations, emissions from use of fuel in facility-owned equipment and vehicle, emissions from the detonation of explosives, etc.). The goal was to estimate the life cycle-based GHGs footprint of In-situ leaching mining and also compare the results with that of conventional methods [20]. In China, [42] also studied on the emissions of 12 non-ferrous metal industries, namely aluminum, lead, zinc, copper, nickel, magnesium, mercury, tin, titanium, tungsten, antimony, and molybdenum for the 2003-2010 period based on their life cycle assessment. Results found that the aluminum, copper, lead, magnesium and zinc industries were the main contributors of GHGs. As far as GHGs emissions are concerned, however, evidences of the implication of LCA in the quarrying industry have been somehow limited in Thailand. Lack of database on life cycle emissions could be associated with the lack of supportive data on quarrying processes, energy use, and equipment and fuel types in mining industry [43]. The aim of this study was therefore to assess all possible environmental and climate change related impacts associated with limestone quarrying operation in Thailand by using a life cycle assessment approach.

\section{MATERIAL AND MeTHODS INTRODUCTION}

\subsection{Case Study}

Limestone quarrying operation (Plant A), located in the central region of Thailand approximately 100 kilometers from Bangkok province, was selected as a case study of this research. Geographically, there are huge deposits of limestone in such particular area, as depicted in Fig. 3 [44]. In terms of their productivity, annual production of about 1417705 tons crushed rock was extensively used as an industrial rock construction. 


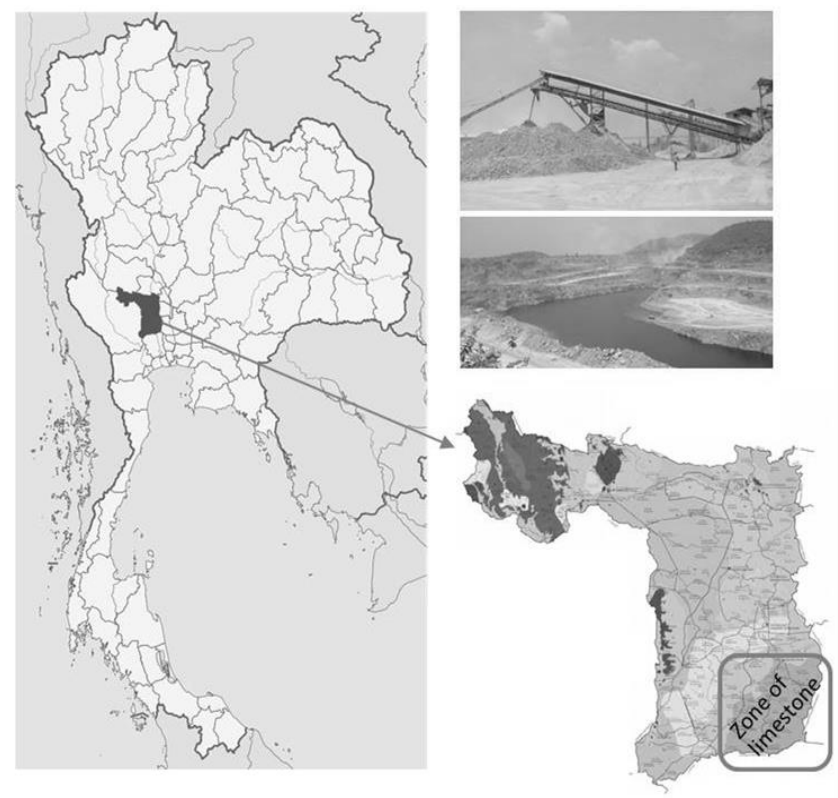

Fig. 3. Geological map of research case study, Central of Thailand [44].

\subsection{LCA Application}

LCA is currently one of the most promising methods used to investigate and also rank environmental impacts of a product, process or related activity. The concept of LCA is well established, internationally acknowledged and systematically defined in the International Organization for Standardization (ISO) 14040 and 14044 [45], [46]. Technically, it is a management tool that considers the quantification of resource consumption and emissions of a product, not only in the production phase, but also in the earlier stages (i.e. extraction of inputs and raw materials) as well as the later stages of the product to its final disposal as waste [37]. In this study, LCA concept can be narrowed down to four main steps, including goal and scope definition and life cycle inventory analysis, life cycle impact assessment and interpretation.

\subsubsection{Goals and Scoping}

The goal of this study was to investigate environmental and climate change impacts related to the production of crushed limestone. Based on the cradle-to-gate approach [35], the scope considered all related impacts generated from the mining process (i.e. mineral extraction, production, and transportation of raw materials) as the cradle to the final delivery of crushed limestone rock as the gate. The production of crushed limestone of the Plant A is composed of three units: (i) mineral extraction, (ii) transportation of raw materials, and (iii) comminution (i.e. crushing and grinding processes) (Fig. 3). In sum, 'one ton of crushed limestone used as an industrial rock-construction' was considered as a functional unit of this assessment.

\subsubsection{Life Cycle Inventory}

For the LCA approach, all the data gathered from the factory were converted into the form of life cycle inventory (LCI) which considered all the operations involved in limestone rock 
production. As shown in Fig. 4, the following data and related inputs used for the production of crushed limestone rock were collected: explosives (i.e. ammonium nitrate fuel oil; ANFO) (unit: kg), electricity (unit: $\mathrm{kWh}$ ) and diesel fuel consumption (unit: 1). LCI analysis was performed using the SimaPro 8.3.0 software.

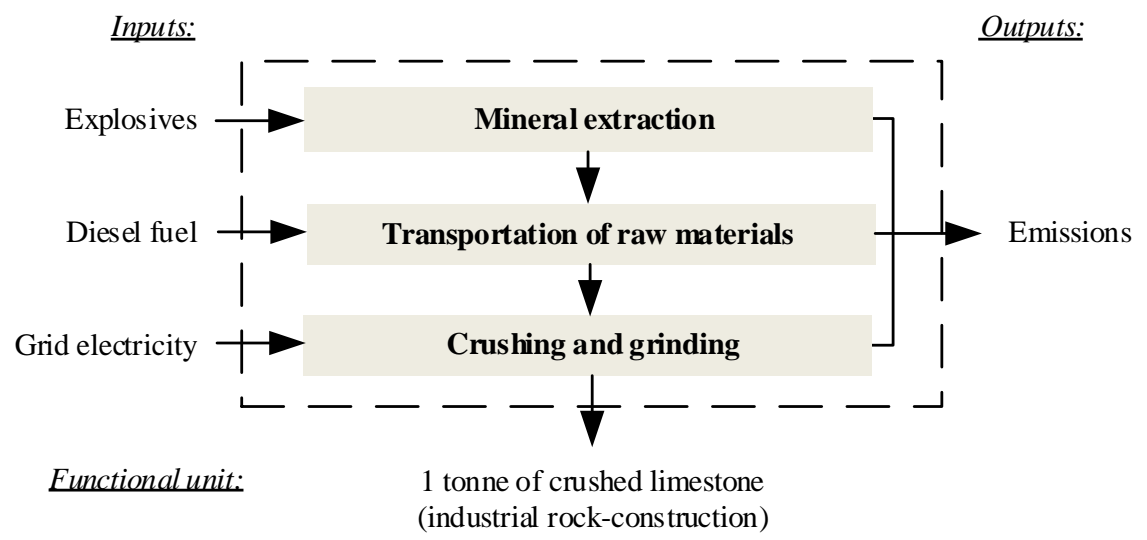

Fig. 4. Flow diagram and system boundaries of limestone quarrying operations of the Plant A.

\subsubsection{Life Cycle Impact Assessment (LCIA)}

To evaluate all environmental and climate change related impacts, both IMPACT 2002+ and the Greenhouse Gas Protocol were emphasized. Firstly, IMPACT 2002+ proposed a feasible implementation of a combined midpoint/damage approach, linking all types of LCI results or all midpoint categories to four damage categories (Fig. 5) [47], [48]. In other words, it is an assessment method providing results both at midpoint and at the damage level which results in lower uncertainty, compared to other endpoint approaches. As example of climate change is that IMPACT 2002+ highlighted the impact of system under analysis on global warming impact category (midpoint) and climate change (damage), giving attention to the emissions of GHGs from energy use (i.e. production and supply of heat and electricity). As earlier stated that all midpoint scores are normally expressed in units of a reference substance and related to the four damage categories, namely i) human health (Disability-Adjusted Life Years: DALY), ii) ecosystem quality (Potentially Disappeared Fraction of species over a certain amount of $\mathrm{m}^{2}:$ PDF $\cdot \mathrm{m}^{2} \cdot \mathrm{y}$ ), iii) climate change (kilogram carbon dioxide equivalents ( $\mathrm{kg} \mathrm{CO}_{2}$ eq.), and iv) resources or the amount of energy extracted or need to extract the resource (MJ) [49], [50]. 


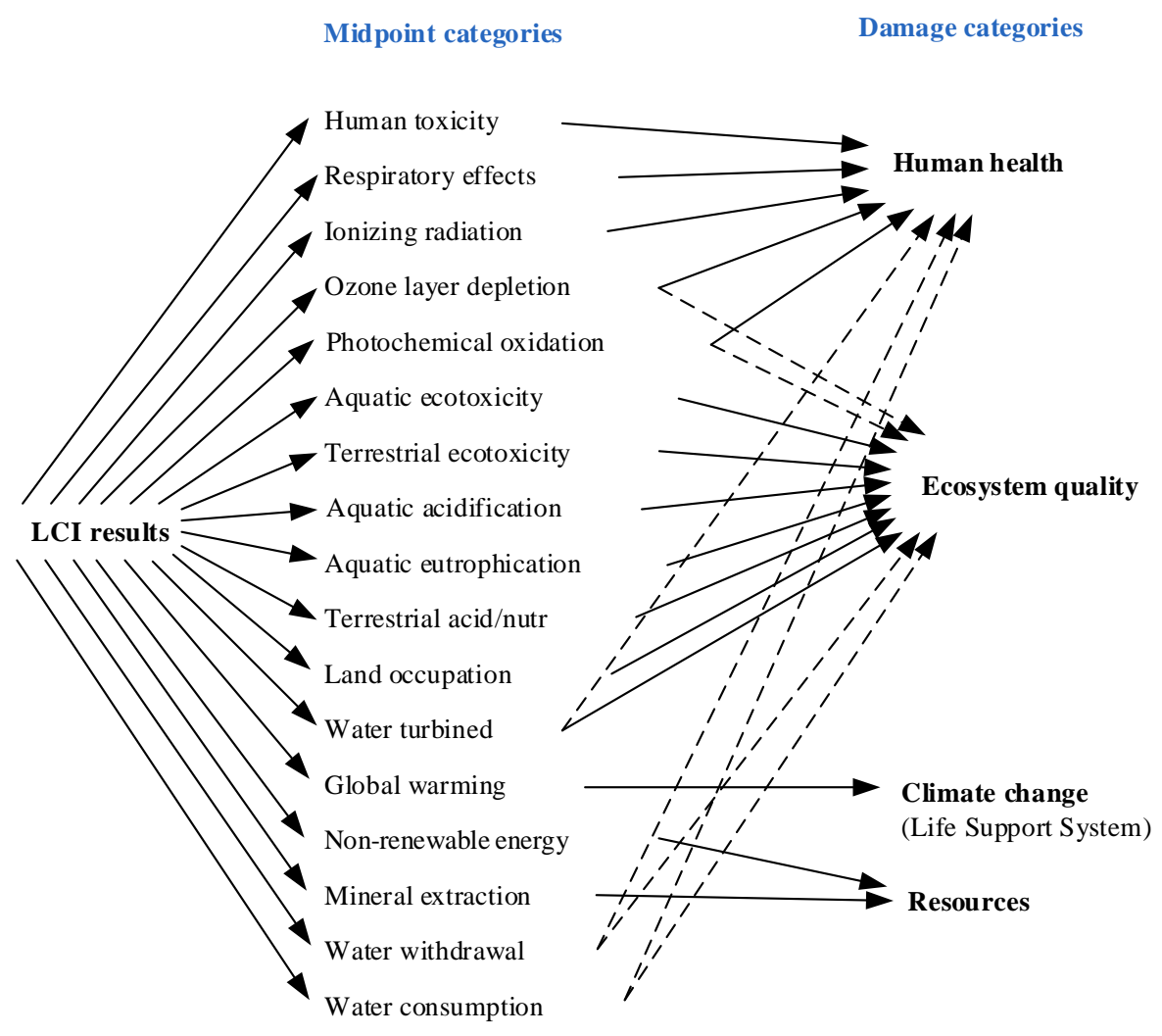

Fig. 5. Concept of IMPACT 2002+: linking LCI via the midpoint categories to four damage categories [50].

Secondly, in terms of climate change impacts, the Greenhouse Gas Protocol developed in 2001 by the World Resources Institute (WRI) and World Business Council for Sustainable Development (WBCSD) [51] was basically used to define and assess all carbon emissions from all of the following sources: fossil based carbon $\left(\mathrm{CO}_{2}\right.$ originating from fossil fuels), biogenic carbon $\left(\mathrm{CO}_{2}\right.$ originating from biogenic sources such as trees and plants), carbon from land transformation and also carbon uptake $\left(\mathrm{CO}_{2}\right.$ that is captured or stored in plants as they grow). By employing the Greenhouse Gas Protocol method, climate change impacts will be assessed and the expressed in the unit of $\mathrm{kg} \mathrm{CO}_{2}$ eq.

\subsubsection{Interpretation}

All LCI and LCIA results were interpreted as the final phase of life cycle analysis. As the impacts aggregation, both normalizing and weighting the estimated environmental impacts were considered to understand the total impacts and to indicate which impacts are most important. 


\section{RESUlTS AND DisCUSSION}

\subsection{LCI Data}

Life cycle inventory (LCI) of this study was defined as a phase of LCA involving the quantification of both inputs and outputs for limestone production. As presented in Table 1, all inputs from technosphere such as materials, fuels or electricity used in the production processes were considered. For the assessment of all related environmental impacts, annual data were collected from the limestone quarrying operation by means of interviews and mine site surveys. In this study, all LCI data were obtained and prepared on the basis of the following reporting documents:

- A report on crushed limestone rock production;

- Monthly data on electricity consumption;

- Monthly data on diesel fuel consumption;

- Blasting permit.

As noted, there was neither co-product nor by-products generated during the mining process. Only crushed stone rock product was therefore considered to be the output to technosphere.

TABLE 1. LIFE CYCLE INVENTORY OF LIMESTONE ROCK PRODUCTION

\begin{tabular}{lllll}
\hline LCI data & & & & \\
\hline Inputs & Process & Unit Per Ton Product & Unit & Data Sources \\
\hline Explosives & Limestone extraction & 0.2786 & kilogram & $\begin{array}{l}\text { Blasting permit; } \\
\text { Interviews }\end{array}$ \\
Diesel oil & $\begin{array}{l}\text { Transportation } \\
\text { Electricity }\end{array}$ & 1.0686 & litre & $\begin{array}{l}\text { Fuel bills; } \\
\text { Interviews }\end{array}$ \\
& $\begin{array}{l}\text { Comminution (crushing } \\
\text { and grinding) }\end{array}$ & 2.9845 & kilowatt hours & $\begin{array}{l}\text { Electricity bills; } \\
\text { Interviews }\end{array}$ \\
\hline $\begin{array}{l}\text { Outputs } \\
\text { Crushed }\end{array}$ & & 1 & ton & $\begin{array}{l}\text { Annual report of } \\
\text { mining company }\end{array}$ \\
\hline
\end{tabular}

\subsection{IMPACT 2002+}

Table 2 presents the results of the environmental impacts assessment of 1 ton crushed limestone rock production by using IMPACT 2002+ method. Principally, all inputs are evaluated the potential environmental impacts through the use of appropriate characterization factors. Based on a specific unit of measurement (i.e. $\mathrm{kg} \mathrm{CO}_{2}$ eq. for $\mathrm{GHG}$ ), the higher value, the greater environmental impact. Regarding to all individual impact categories (Fig. 6), the analysis of climate change related impacts showed that the amount of process-related GHGs emissions in the limestone quarrying operation were about $2.76 \mathrm{~kg} \mathrm{CO}_{2}$ eq. Electricity consumption for crushing and grinding processes was by far the dominant source of $\mathrm{CO}_{2}$ emissions $(51 \%)$. The total depletion of non-energy resources was 79.6 MJ per one ton crushed limestone rock production. Diesel fuel utilization impact was more commonly found in the mining operations. For the other impacts, use of chemical explosives in the limestone mining extraction may pose a greater risk to both human health (i.e. carcinogen, non-carcinogens) and ecosystem (i.e. aquatic and terrestrial ecotoxicity, land occupation, aquatic eutrophication and mineral extraction). Overall, comparatively, Lelek [49] also investigated the potential impacts of energy generation upon the environment in Poland in 2007, 2010, and 2012 by IMPACT 2002+ method. The results found 
that the main environmental impacts were global warming, non-renewable energy, respiratory disorder resulting from the emissions of inorganic compound, and terrestrial ecotoxicity, respectively.

TABLE 2. LCIA RESULTS OF LIMESTONE QUARRYING OPERATION USING IMPACT 2002+ BY IMPACT CATEGORY

\begin{tabular}{|c|c|c|}
\hline \multirow{2}{*}{$\frac{\text { Impact category }}{\text { Carcinogens }}$} & \multicolumn{2}{|c|}{ Unit (characterization) } \\
\hline & 0.0193 & $\mathrm{~kg} \mathrm{C}_{2} \mathrm{H}_{3} \mathrm{Cl}$ eq. \\
\hline Non-carcinogens & 0.0148 & $\mathrm{~kg} \mathrm{C}_{2} \mathrm{H}_{3} \mathrm{Cl}$ eq. \\
\hline Respiratory inorganics & 0.00226 & kg PM 2.5 eq. \\
\hline Ionizing radiation & 34 & Bq C-14 eq. \\
\hline Ozone layer depletion & $1.75 \times 10^{-7}$ & $\mathrm{~kg} \mathrm{CFC}-11$ eq. \\
\hline Respiratory organics & 0.000599 & $\mathrm{~kg} \mathrm{C}_{2} \mathrm{H}_{4}$ eq. \\
\hline Aquatic ecotoxicity & 47.2 & kg TEG water \\
\hline Terrestrial ecotoxicity & 16 & kg TEG soil \\
\hline Terrestrial acid/nutri & 0.0517 & $\mathrm{~kg} \mathrm{SO}_{2}$ eq. \\
\hline Land occupation & 0.0426 & $\mathrm{~m}^{2}$ org.arable \\
\hline Aquatic acidification & 0.0143 & $\mathrm{~kg} \mathrm{SO}_{2}$ eq. \\
\hline Aquatic eutrophication & 0.000137 & $\mathrm{~kg} \mathrm{PO}_{4}$ P-lim \\
\hline Global warming & 2.76 & $\mathrm{Kg} \mathrm{CO}_{2}$ eq. \\
\hline Non-renewable energy & 79.6 & MJ \\
\hline Mineral extraction & 0.061 & MJ \\
\hline
\end{tabular}

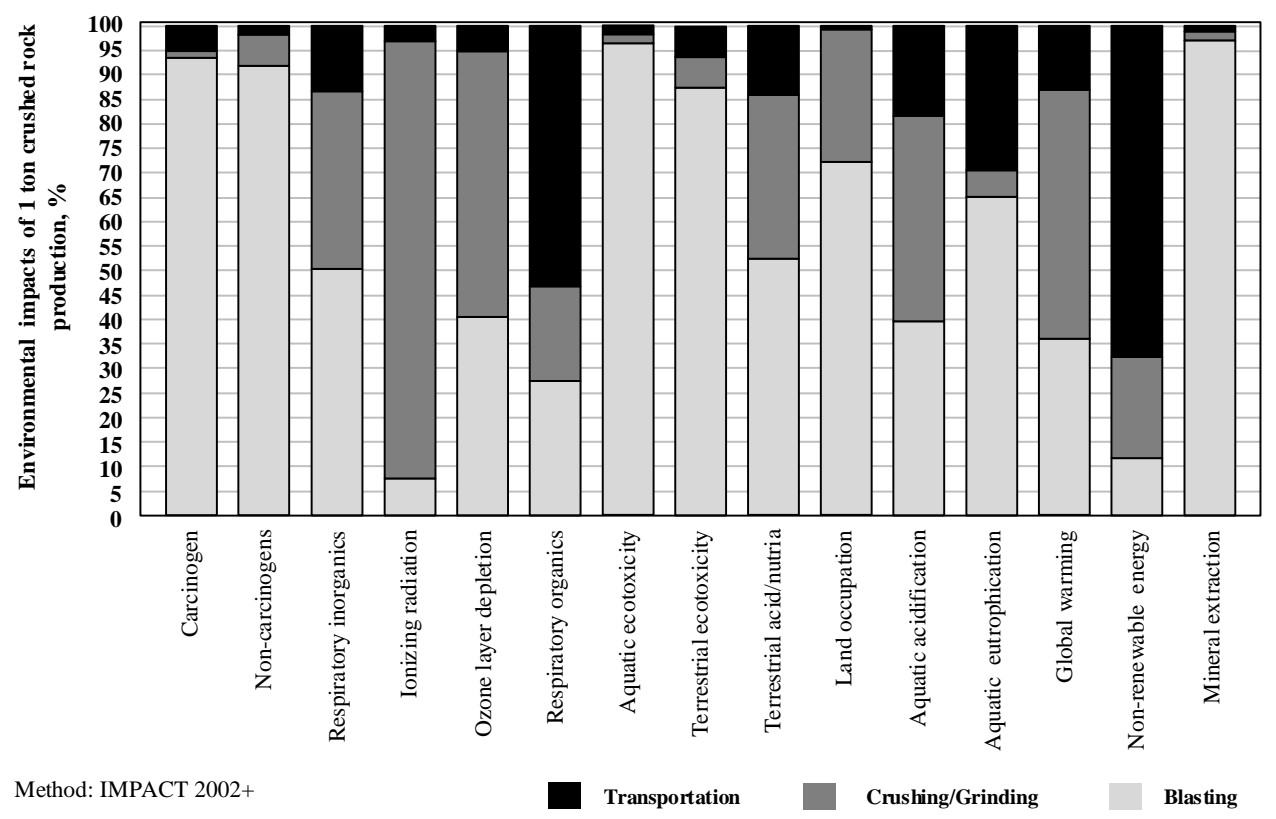

Fig. 6. Characterization of environmental impacts of 1 ton crushed limestone rock production by IMPACT 2002+, \% . 
As depicted in Fig. 7, all midpoint scores of the above individual impact categories were aggregated to the four damage categories: human health, ecosystem quality, climate change and resources. It can be seen that 'resources category' (i.e. the sum of non-renewable energy consumption and mineral extraction midpoint categories) presented the greatest environmental impacts. Diesel fuel consumption for transport operations accounted for over $60 \%$ of the resources category. These results were consistent with Ditsele [14] revealed that the assessed potential energy use impacts of the surface coal mining in the United States were about 97-81 MJ/ton product. The biggest contributor to energy use impact for one tone of coal production was the use of diesel energy source. In this study, climate change was the second largest impact on environment. Electricity used by the limestone processing plant for crushing and grinding presented the highest potential of climate change impact of $1.41 \mathrm{~kg} \mathrm{CO}_{2}$ eq./ton of crushed limestone rock. In cement and concrete production, it also has been pointed out previously [33] that GHGs emissions from the quarrying, cement manufacturing and concrete production in the United States were approximately 104 million $\mathrm{t} \mathrm{CO}_{2}$ eq. In each case, the production of concrete accounted for over $20 \%$ of the energy and $12 \%$ of $\mathrm{CO}_{2}$ emissions. Also, potential human health impacts from the limestone mining operations, especially blasting process, have been identified. The results of the current analysis were also consistent with previous research. For instance, Kukfisz [52] reported that human health was the main categories of damage $(70.62 \%$ of total impacts) involved in the production of mining blasting materials.

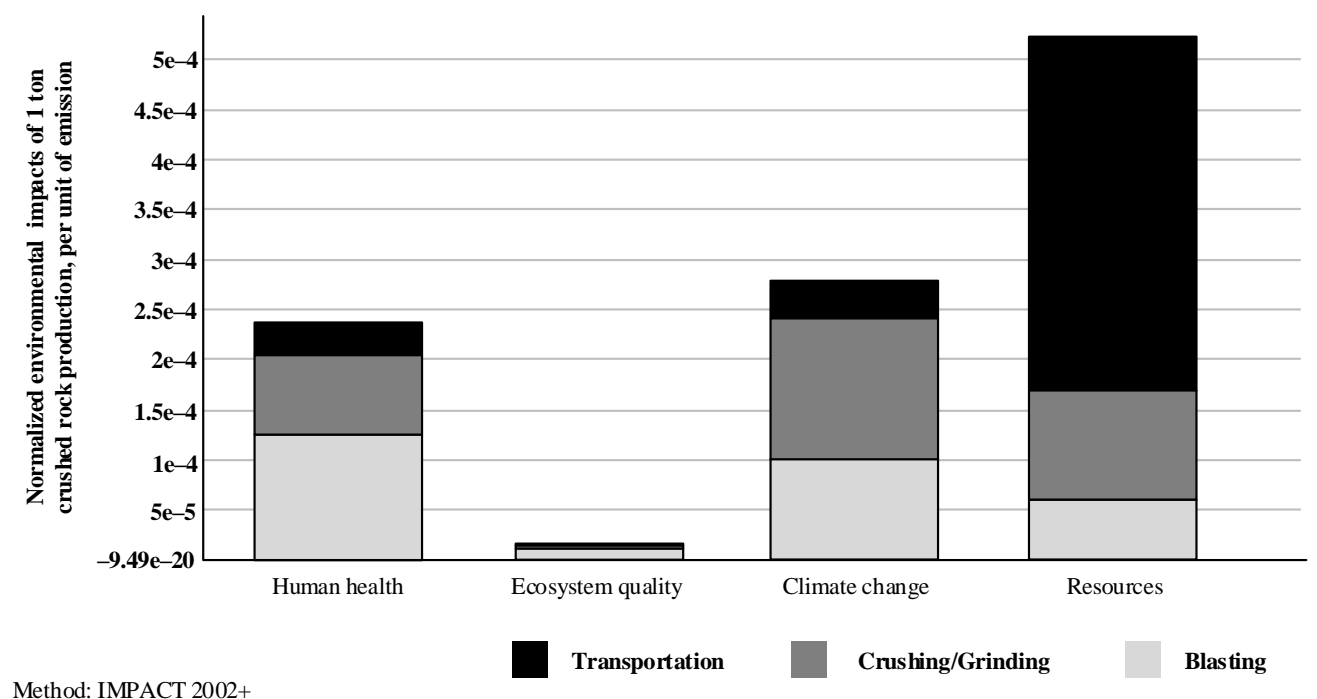

Fig. 7. Normalized environmental impacts of 1 ton crushed limestone rock production (LCIA: IMPACT 2002+).

The results of the current analysis are consistent with previous research. For instance, several studies including Yahaya [53], Kittipongvises [54], Carras [55], Sterling [56] as well as in that one of Silva [57] reported that over half of all electricity consumed in the mining operation was mainly used for crushing and grinding processes. A study by [57] also indicated that energy consumption was the main environmental impact associated to the phosphate rock mining. Of this, approximately $85 \%$ of the total energetic demand was used in the primary crushing, classification and homogenization processes. In a similar manner, Norgate [11] found that the utilization of 
electricity for the mining and comminution processes made the greatest contribution to the GHGs footprint of gold production with responsible for more than half of the total emissions. Wang [58] reported that the energy distribution was governed by grinding $(80 \%-90 \%)$ and crushing $(3 \%-5 \%)$ in the mining process and production. As is mentioned, crushing and grinding alone can account for more than half $(60 \%)$ of mine electrical power load and more than $35 \%$ of GHGs emissions for operation of the mine [59]. Improving energy efficiency of grinding processes is widely considered as one of the most promising means to lower GHGs emissions [60]. Upgrading electrical system in the semi-autogenous grinding (SAG) resulted in $20 \%$ net energy improvement leading to a net GHGs reduction of about $43000 \mathrm{t} \mathrm{CO}_{2}$ per year [61]. However, because there was no chemical used in the extraction process of crushed rock mining, this study showed low-risk level for both life cycle carcinogenic and heavy metal emissions (Fig. 4). In contrast, compared to other mines, Ferreira [35] revealed that emissions of inhalable compounds (i.e. $\mathrm{PM}_{10}$ and $\mathrm{PM}_{2.5}$ ) and carcinogenic substances (i.e. $\mathrm{Cd}$ and As) were highly associated with adverse health impacts in the iron ore production. Further to this, Schreiber [62] found out that human toxicity was the predominant cause of environmental impacts of the rare earth mining (i.e. neodymium and dysprosium) with a share of $33 \%-49 \%$ of the total impacts.

\subsection{Greenhouse Gas Protocol}

Based on the Greenhouse Gas Protocol calculation method, using the above inventory analysis, the total GHGs emissions from limestone quarrying operation of this study was approximately $3.13 \mathrm{~kg}$ carbon dioxide equivalents $\left(\mathrm{kg} \mathrm{CO}_{2}\right.$ eq.) per ton crushed rock product which was not too different from the previous finding. As such, Norgate [15] reported the total emissions of $4.9 \mathrm{~kg} \mathrm{CO}_{2}$ eq. per ton of ore in the bauxite mining process. Furthermore, in this study, electricity utilization for crushing and grinding processes in the limestone mining industry were the most important sources of GHGs, accounting for about $46.8 \%$ of total fossil-fuel $\mathrm{CO}_{2}$ emissions. Compared to other previous studies, in uranium mining and milling, the biggest share of the $\mathrm{CO}_{2}$ process emissions was energy consumption $(71 \%)$. Of this total, about $40 \%$ of total energy-related emission was derived mainly from grid-power utilization [20]. On the contrary, some of the studies argued that the largest share of $\mathrm{CO}_{2}$ emissions came mainly from the transport activities associated with diesel fuel consumption in the mining operation. For instance, Norgate [15] specifically found that diesel consumption for both loading and hauling fleet in the mining of iron ore and bauxite make the largest contributions (50\%) to total GHGs emission. Sjunnesson [63] speculated that about $36 \%$ of total GHGs emissions came from diesel used for aggregate transportation. Meanwhile, the use of explosives was emitted in small quantities. Similar results have also been observed by the studies of Ercelebi [64], Dindarloo [65], Kittipongvises and Dubsok [66], [67] found that direct emission from transport-related activities in the quarrying process (i.e. transportation of rock from the mine the plant) was considered to be the largest share of emissions compared to other sources. Based on the LCA application, Ditsele [14] observed that emission from diesel use was reflected in the dominance of climate change impact in coal mining industry (23.5\%-75.5\% of total GHGs emissions). This, in turn, Ferreira [35] pointed out that the consumption of electricity and diesel fuel in the mining industry was by far the largest contributor to the climate change impacts. By employing the Greenhouse Gas Protocol-LCA method, the results of this study further showed that carbon emissions from both biogenic source and land transformation represented relatively low emissions (Fig. 8). 


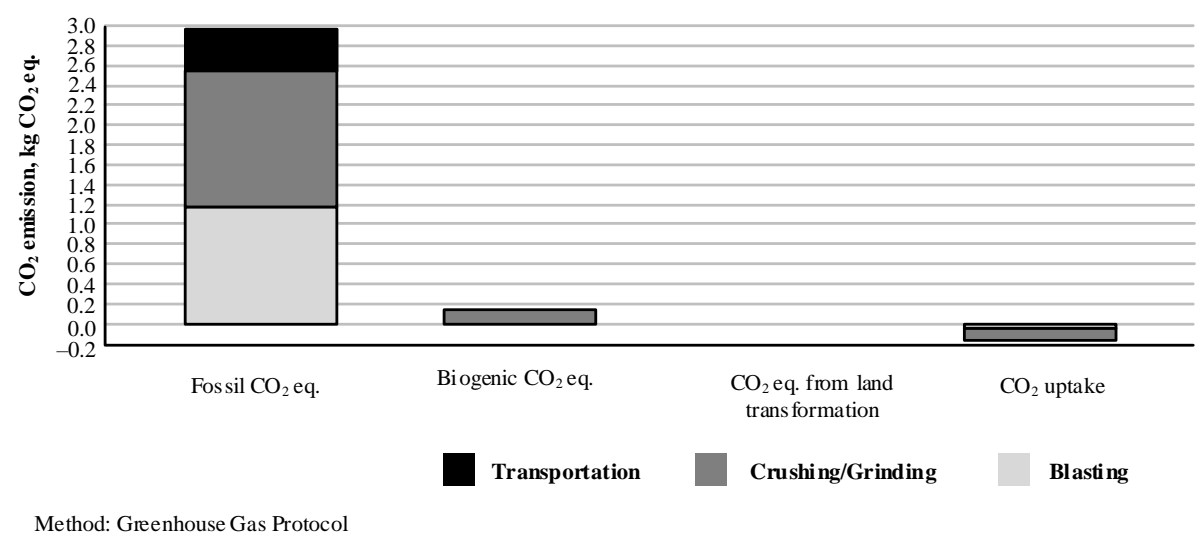

Fig. 8. Climate change impacts of limestone quarrying operation based on LCIA: Greenhouse Gas Protocol (kg $\mathrm{CO}_{2}$ eq.).

From the above impact assessments, it can be seen that energy used in the processes was the most significant environmental and climate change impacts in the limestone production. In the literature, some of the potential technologies and options to lower both energy and GHGs emissions from the mining sector are given below. However, it should be noted that feasibility of each mitigation option will mainly depend on the individual factory circumstances.

\subsubsection{Improve the Energy Efficiency of Mining Equipment}

In the mining sector, the US department of energy [68] revealed that the metal mining sector in the United States has the potential to cut their energy consumption by $61 \%$ from existing practice to the best-estimated practical minimum energy consumption. Through this strategy, [55] reviewed some technical measures to avoid and reduce carbon emissions in the operation of the mine, especially comminution, include high pressure grinding roll, vertical roller mills and microwave heating technology.

\subsubsection{Development of Clean and Renewable Energy Technologies}

In light of rising public concern over the depletion of resources and GHGs footprint of the mineral processing, the adoption of clean alternative fuel vehicles and climate technologies is suggested as a viable perspective for the mining operator. According to the analysis of the environmental footprint of primary copper supply by Mudd [69], the switch to alternative renewable energy, especially solar thermal plus biodiesel, could potentially have profound impact

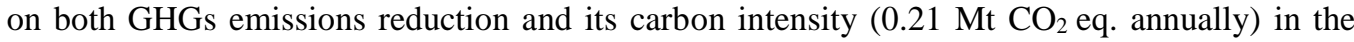
copper sector. As anticipated, only by changing energy source (i.e. electricity) to solar energy could potentially achieve $81 \%$ reduction in GHGs emissions per year from copper production even without biodiesel. Further to this, haul truck payload management, In-pit crushing and conveying (IPCC), and reduction in total rolling resistance of vehicle tires has the potential to contribute to the reduction of $\mathrm{CO}_{2}[66]$.

\subsubsection{Limitations of this Study and Other Environmental Impacts}

In accordance with the results obtained, the production of one ton crushed limestone rock was connected with all related environmental impacts, especially climate change, the depletion of resources, ecosystem quality and human health. However, a recognised limitation of this LCA 
study is that most of the LCI data was obtained from mining documents (i.e. a report on limestone rock production, blasting permit, electricity and diesel fuel bill). Thus, there is some degree of uncertainties in the input data, as the following details below.

\subsubsection{Data Uncertainty}

Lack of database on some specific mining operating conditions can also contribute to the uncertainty of the results of LCA study. For example, there were no data available on the assessment of fugitive atmospheric emissions, especially the leakages from the machinery and equipment, from the mining operations. However, it has been pointed out that these emissions are difficult to accurately estimate and there remains substantial uncertainty which are proportional to type, age and quality of equipment [70]. It would suggest that all fugitive emissions from the mineral production processes (i.e. exploration, production, processing and transportation) should be investigated and documented. In addition, uncertainty of the results may arise from the limited availability of each activity data. For instance, the amount of mine site's fuel consumption was not separately reported by each production activity, such as the amount of diesel fuel spent by the machinery at working site. In this context, it is important to separately collect data on the amount of fuel consumption during each phase of the mining life cycle, such as for drilling operation, charging explosives in the boreholes, blasting and for all processes related to daily operations. Better quality and more representative LCI-input data are required. To identify parameters that could potentially contribute to the uncertainty of the LCIA results, sensitivity analysis of specific parameters, such as blasting techniques, ore grade production plan [11], should be also systematically adopted in further research.

\subsubsection{Other Environmental Impacts}

A lack of measured data for some parameters was one of the main cause of uncertainty that could somehow affect the LCA results. Based on staff interviews and site observation in this study, there were neither bulky nor chemical wastes generated during the production processes of crushed limestone rock. Only dust was emitted from crushing and grinding processes, but there was no data record on the emissions of air pollutants in each production process. Through this assessment, limestone waste from the quarrying operation (i.e. crushing and grinding) was assumed to be zero. Recognizing this, multiple sources of all atmospheric pollutants (i.e. TSP, $\mathrm{PM}_{10}$, blasting fumes, etc.), such as air emissions from drilling, blasting, crushing and grinding processes, and traffic on unpaved roads should be systematically accounted and included in the assessment of environmental impacts of the quarrying operation. In terms of water resource, all necessary data for the assessment of water use impact was also not available for this case study. As the water footprints are other environmental concerns in the mining industry [11], these impacts should be therefore investigated further.

\section{Conclusion}

In Thailand, limestone is the primary raw material for crushed rock, and its demand is expected to increase significantly over time. However, the impacts of mineral processing on the environment have been considered one of the public's concerns. Extraction and processing of mineral resources is basically associated with considerable environmental and climate burdens. These include the contamination of water, soil, air, the depletion of natural resources and climate change related impacts. To promote sustainable mining practices, the use of LCA as 
a decision-making support makes it possible to explore ecological and human health impacts over the complete life cycle of the products and services. There is however a lack of reference data in GHGs emissions and environmental burdens related to aggregate production in Thailand. Therefore, the focus in this paper has been on the assessment of all possible environmental and climate change related impacts of limestone quarrying operation in Thailand. The production of crushed limestone of the Plant A was chosen as representative of this study. By considering life-cycle assessment, all three stages of limestone rock production, namely extraction, transportation, and comminution (i.e. crushing and grinding) were systematically examined. In this scope, LCA includes both life cycle inventory (LCI) and life cycle impact assessment (LCIA). The functional unit selected in this study was 1 ton crushed limestone rock production. As in a life-cycle inventory, the utilization of electricity, diesel fuel, and explosive in the mining processes were included as inputs from the technosphere. In a LCIA, both IMPACT 2002+ and the Greenhouse Gas Protocol methods were employed to evaluate all related environmental and climate change impacts of limestone quarrying activities. The results revealed that, by using IMPACT 2002+, the total depletion of non-energy resources and the amount of process-related GHGs emissions were $79.6 \mathrm{MJ}$ and $2.76 \mathrm{~kg} \mathrm{CO}_{2}$ eq. per ton crushed limestone rock production, respectively. Electricity used in comminution process was the dominant source of $\mathrm{CO}_{2}$ emissions. For the other impacts, extraction process associated with blasting operations may pose a potential risk to both human health and ecological receptors. According to the four damage categories, the assessment results also highlighted that resource category was by far the greatest environmental impacts of the limestone rock production. The use of diesel fuel in the transportation process was the main cause for resource depletion. Climate change damage category was the second most significant contribution. The GHGs emissions $\left(\mathrm{CO}_{2}\right.$ eq.) were mainly from the consumption of electricity for crushing and grinding processes. With regards to specific climate change impacts, by employing the Greenhouse Gas Protocol method, the total emissions of GHGs was 3.13 per ton crushed rock product. Compared to IMPACT 2002+ assessment, similar results were obtained. Electrical energy consumption was the major driver of climate change impact. Data uncertainties in assessments of environmental and climate change related impacts have to be carefully considered. In overall terms, it is also a major challenge for the mining operator to continue their effort to develop and promote the use of modern technologies that improve energy efficiency, reduce GHGs emissions and also ensure environmental integrity. The concept of integrated life cycle sustainability assessment (ILCSA) of the mining and mineral-related products should be more emphasized in further studies.

\section{ACKNOWLEDGEMENT}

The author thanks the Office of Higher Education Commission (OHEC) and the S\&T Postgraduate Education and Research Development Office (PERDO) for the financial support of the Research Unit of Green Mining Management (GMM) and Research Program and thanks the Ratchadaphiseksomphot Endowment Fund, Chulalongkorn University for the Research Unit. The author also would like to express my sincere thanks to the Environmental Research Institute (ERIC) and the Center of Excellence on Hazardous Substance Management (HSM) Chulalongkorn University for their invaluable supports in terms of facilities and scientific equipment.

\section{REFERENCES}

[1] Kittipongvises S., Polprasert C. GHGs Emissions and Sustainable Solid Waste Management. In Recycling of Solid Waste for Biofuels and Bio-chemicals. Springer: Singapore, 2016:55-85.

doi:10.1007/978-981-10-0150-5 3 
[2] Olivier J. G. J., Janssens-Maenhout G., Muntean M., Peters J. A. H. W. Trends in global CO 2 emissions. 2016 Report. The Hague: PBL Netherlands Environmental Assessment Agency, 2016.

[3] IPCC. Climate Change 2014: Synthesis Report. Contribution of Working Groups I, II and III to the Fifth Assessment Report of the Intergovernmental Panel on Climate Change. Geneva: IPCC, 2014.

[4] EPA. Climate change indicators in the United States: global greenhouse gas emissions. Report [Online]. [Accessed 23.01.2017]. Available: http://www/epa.gov/climatechange/indicators

[5] IPCC. Summary for Policymakers. Climate Change 2014: Mitigation of Climate Change. Contribution of Working Group III to the Fifth Assessment Report of the Intergovernmental Panel on Climate Change. Cambridge: Cambridge University Press, 2014.

[6] Fischedick M., Roy J., Abdel-Aziz A., Acquaye A., Allwood J. M., Ceron J.-P., Geng Y., Kheshgi H., Lanza A., Perczyk D., Price L., Santalla E., Sheinbaum C., Tanaka K. 2014: Industry. Climate Change 2014: Mitigation of Climate Change. Contribution of Working Group III to the Fifth Assessment Report of the Intergovernmental Panel on Climate Change. Cambridge: Cambridge University Press, 2014.

[7] Office of Natural Resources and Environmental Policy and Planning. Thailand's First Biennial Update Report under the United Nations Framework Convention on Climate Change. [Online]. Available: http://unfccc.int/resource/docs/natc/thabur1.pdf

[8] Office of the National Economic and Social Development Board (NESDB). Climate Change. Bangkok: Pomprab, 2015.

[9] Department of Primary Industries and Mines. Status of mineral resources utilization in Thailand in 2013-2014 [Online]. [Accessed 7.02.2017]. Available: http://www1.dpim.go.th/dt/pper/000001437122620.pdf

[10] East Sussex, South Downs and Brighton \& Hove. Information Paper 9 Climate Change and Waste and Minerals. [Online]. [Accessed 12.02.2017]. Available: http://www.eastsussex.gov.uk/NR/rdonlyres/1459A461-10CA-48D086C2-D3B558BD70AC/0/information_paper_9.pdf

[11] Norgate T., Haque N. Using life cycle assessment to evaluate some environmental impacts of gold production. Journal of Cleaner Production 2012:29-30:53-63. doi:10.1016/j.jclepro.2012.01.042

[12] Liu F., Cai Q., Chen S., Chen S., Zhou W. A comparison of the consumption and carbon emissions for different modes of transportation in open-cut coal mines. International Journal of Mining Science and Technology 2015:25:261-266. doi:10.1016/j.ijmst.2015.02.015

[13] Morrow III W. R., Hasanbeigi A., Sathaye J., Xu T. Assessment of energy efficiency improvement and $\mathrm{CO}_{2}$ emission reduction potentials in India's cement and iron \& steel industries. Journal of Cleaner Production 2014:65:131-141. doi:10.1016/i.jclepro.2013.07.022

[14] Ditsele O. Application of life cycle assessment to estimate environmental impacts of surface coal mining. Master's thesis, Missouri University of Science and Technology, 2010.

[15] Norgate T., Haque N. Energy and greenhouse gas impacts of mining and mineral processing operations. Journal of Cleaner Production 2010:18(3):266-274. doi:10.1016/j.jclepro.2009.09.020

[16] Peralta S., Sasmito A. P., Kumral M. Reliability effect on energy consumption and greenhouse gas emissions of mining hauling fleet towards sustainable mining. Journal of Sustainable Mining 2016:15(3):85-94 doi:10.1016/j.jsm.2016.08.002

[17] Moran C. J., Lodhia S., Kunz N. C., Huisingh D. Sustainability in mining, minerals and energy: New processes, pathways and human interactions for a cautiously optimistic future. Journal of Cleaner Production 2014:84:1-15. doi:10.1016/j.jclepro.2014.09.016

[18] United Nations. Sustainable Development Goals (SDGs). [Online]. [Accessed 16.10.2017]. Available: http://www.un.org/sustainabledevelopment/sustainable-development-goals/\#

[19] Niyomthai S., Wattanawan A. Sustainable mining in Thailand: Paradigm shift in environmental management. Applied Environmental Research 2014:36:55-63. doi:10.14456/aer.2014.13

[20] Parker D. J., McNaughton C. S., Sparks G. A. Life cycle greenhouse gas emissions from uranium mining and milling in Canada. Environmental Science \& Technology 2016:50:9746-9753. doi:10.1021/acs.est.5b06072

[21] Baumann H., Tillman A. The Hitch Hiker's Guide to LCA: An orientation in Life Cycle Assessment Methodology and Application. Lund: Studentlitetteratur, 2004.

[22] Chauhan M. K., Chaudhary V. S., Kumar, S., Samar. Life cycle assessment of sugar industry: A review. Renewable and Sustainable Energy Reviews 2011:3445-3453. doi:10.1016/j.rser.2011.04.033

[23] Luo L., van der Voet E., Huppes G. Life cycle assessment and life cycle costing of bioethanol from sugarcane in Brazil. Renewable and Sustainable Energy Reviews 2009:13:1613-1619. doi:10.1016/j.rser.2008.09.024

[24] Silva D. A. L., Delai I., Montes M. L. D., Ometto A. R. Life cycle assessment of the sugarcane bagasse electricity generation in Brazil. Renewable and Sustainable Energy Reviews 2014:532-547. doi:10.1016/j.rser.2013.12.056

[25] Sumper A., Robledo-Garcia M., Villafafila-Robles R., Bergas-Jane J., Andres-Peiro J. Life-cycle assessment of a photovoltaic system in Catalonia (Spain). Renewable and Sustainable Energy Reviews 2011:15:3888-3896. doi:10.1016/j.rser.2011.07.023

[26] Parisi M. L., Maranghi S., Basosi R. The evolution of the dye sensitized solar cells from Grätzel prototype to up-scaled solar applications: a life cycle assessment approach. Renewable and Sustainable Energy Reviews 2014:39:124-138. doi:10.1016/j.rser.2014.07.079 
[27] Ardente F., Beccali M., Cellura M., Brano V. L. Energy performances and life cycle assessment of an Italian wind farm. Renewable and Sustainable Energy Reviews 2008:12:200-217. doi:10.1016/j.rser.2006.05.013

[28] Arvesen A., Hertwich E. G. Assessing the life cycle environmental impacts of wind power: a review of present knowledge and research needs. Renewable and Sustainable Energy Reviews 2012:16:5994-6006. doi:10.1016/j.rser.2012.06.023

[29] Bolin C. A., Smith S. T. Life cycle assessment of pentachlorophenol-treated wooden utility poles with comparisons to steel and concrete utility poles. Renewable and Sustainable Energy Reviews 2011:15:2475-2486. doi:10.1016/j.rser.2011.01.019

[30] Lee K., Tae S., Shin S. Development of a life cycle assessment program for building (SUSB-LCA) in South Korea. Renewable and Sustainable Energy Reviews 2009:13:1994-2002. doi:10.1016/j.rser.2009.01.002

[31] Zhang X., Shen L., Zhang L. Life cycle assessment of the air emissions during building construction process: a case study in Hong Kong. Renewable and Sustainable Energy Reviews 2013:17:160-169. doi:10.1016/j.rser.2012.09.024

[32] Orabi W., Zhu Y., Ozcan-Deniz G. Minimizing Greenhouse Gas Emissions from Construction Activities and Processes. Construction Research Congress. Reston, VA: American Society of Civil Engineers, 2012. doi: $10.1061 / 9780784412329.187$

[33] Choate W. T. Energy and Emission Reduction Opportunities for the Cement Industry. Columbia: BCS Incorporated, 2003.

[34] Ma F., Sha A., Yang P., Huang Y. The Greenhouse Gas Emission from Portland Cement Concrete Pavement Construction in China. International Journal of Environmental Research \& Public Health 2016:13(7):632. doi:10.3390/ijerph13070632

[35] Ferreira H., Leite M. G. P. A life cycle assessment study of iron ore mining. Journal of Cleaner Production 2015:108:1081-1091. doi:10.1016/j.jclepro.2015.05.140

[36] Awuah-Offei K., Adekpedjou A. Application of life cycle assessment in the mining industry. Journal of Life Cycle Assessment 2011:16:82-89.

[37] Blengini G. A., Garbarino E., Solar S., Shields D. J., Hamor T., Vinai R., Agioutantis Z. Life cycle assessment guidelines for the sustainable production and recycling of aggregates: the Sustainable aggregates Resource Management Project (SARMa). Journal of Cleaner Production 2012:27:177-181. doi:10.1016/j.jclepro.2012.01.020

[38] Northey S., Haque H., Mudd G. Using sustainability reporting to assess the environmental footprint of copper mining. Journal of Cleaner Production 2012:40:118-128. doi:10.1016/j.jclepro.2012.09.027

[39] Bruch K. H., Kogler C., Kruger J., Reuter M., Ropenack I. V., Rombach E. Fact statement of an ecological statement of copper production and processing. METALL 1995:49(4):252-7.

[40] Anna M. K. A cradle-to-gate life cycle assessment of primary aluminium production at Norðurál, Master's thesis, University of Iceland, 2014.

[41] Mudd G. M. Global trends in gold mining: towards quantifying environmental and resource sustainability? Resources Policy 2007:32:42-56. doi:10.1016/j.resourpol.2007.05.002

[42] Shao C., Guan Y., Wan Z., Chu C., Ju M. Performance analysis of $\mathrm{CO}_{2}$ emissions and energy efficiency of metal industries in China. Journal of Environmental Management 2014:134:30-138. doi:10.1016/j.jenvman.2013.12.025

[43] DOE. Mining Industry Energy Bandwidth Study. US Depart of Energy, Industrial Technologies Program, 2007. [Online]. Available: https://www1.eere.energy.gov/manufacturing/resources/mining/pdfs/mining_bandwidth.pdf

[44] Department of Mineral Resources, Ministry of Natural Resources and Environment. Classification and distribution of mineral deposit of Suphanburi, Thailand. Report (Thai version), 2014.

[45] ISO 14040: Environmental Management - Life Cycle Assessment - Principles and Framework. International Organization for Standardization. Geneva: 2006.

[46] ISO 14044: Environmental Management - Life Cycle Assessment - Requirements and Guidelines. International Organization for Standardization. Geneva: 2006.

[47] Lewandowska A., Noskowiak A., Pajchrowski G., Zarebska J. Between full LCA and energy certification methodology - a comparison of six methodological variants of buildings environmental assessment. The International Journal of Life Cycle Assessment 2015:20(1):9-22.

[48] Jolliet O., Margni M., Charles R., Humbert S., Payet J., Rebitzer G., Rosenbaum R. IMPACT 2002+: a new life cycle impact assessment methodology. The International Journal of Life Cycle Assessment 2003a:10:324-330.

[49] Lelek L., Kulczycka J., Lewandowska A., Zarebska J. Life cycle assessment of energy generation in Poland. The International Journal of Life Cycle Assessment 2015:21(1):1-14. doi:10.1007/s11367-015-0979-3

[50] Jolliet O., Brent A., Goedkoop M., Itsubo N., Mueller-Wenk R., Pena C., Schenk R., Stewart M., Weidema B. LCIA Definition Study of the SETAC-UNEP Life Cycle Initiative. UNEP, 2003. Available: http://www.uneptie.org/pc/sustain/lcinitiative/

[51] World Resources Institute, World Business Council for Sustainable Development. The Greenhouse Gas Protocol. A Corporate Accounting and Reporting Standard. Revised edition, 2001.

[52] Kukfisz B., Maranda A. Application of the life cycle assessment (LCA) method for assessing the impact of mechanically loaded mining blasting materials on the environment. Chemik 2014:68(1):29-38.

[53] Yahaya N. R., Murad M., Morad N., Fizri F. F. A. Environmental impact of electricity consumption in crushing and grinding processes of traditional and urban gold mining by using life cycle assessment (LCA). Iranica Journal of Energy \& Environment 2012:3:66-73. doi:10.5829/idosi.ijee.2012.03.05.11 
[54] Kittipongvises S. Feasibility of Applying Clean Development Mechanism and GHG Emissions Reductions in the Gold Mining Industry: A Case of Thailand. Environmental and Climate Technologies 2012:15:34-47. doi:10.1515/rtuect-2015-0004

[55] Carras J. N., Day S. J., Saghafi A., Williams D. J. Greenhouse gas emissions from low-temperature oxidation and spontaneous combustion at open-cut coal mines in Australia. International Journal of Coal Geology 2009:78:161-168. doi:10.1016/j.coal.2008.12.001

[56] Sterling D. Identifying opportunities to reduce the consumption of energy across mining and processing plants. Schneider Electric publication 2009:3(2):234-241.

[57] Silva G. A., Kulay L. A. Application of Life Cycle Assessment to the LCA case studies single superphosphate production. International Journal of Life Cycle Assessment 2003:8(4):209-214.

[58] Wang C., Nadolski S., Mejia O., Drozdiak J., Klein B. Energy and cost comparisons of HPGR based circuits with the SABC circuit installed at the huckleberry mine. 45th Annual Canadian Mineral Processors Operators Conference, Ottaea, Ontario, January 22-24, 2013.

[59] Lopez Pacheco A. Mill mods save money. Canadian Institute of Mining Metallurgy and Petroleum, [Online]. Available: https://www.cim.org/en/Publications-and-Technical-Resources/Publications/CIMMagazine/August2012/Upfront/Mill-mods-savemoney. aspx?page=1\#sthash.jdDaqBA8.dpuf.

[60] Jeswiet J., Szekeres A. Energy Consumption in Mining Comminution. Procedia 2016:48:140-145. doi:10.1016/i.procir.2016.03.250

[61] Buckingham L., Dupont F.-F., Stieger J., Blain B., Brits C. Improving Energy Efficiency in Barrick Grinding Circuits [Online]. [Accessed: 18.10.2017]. Available: https://www.eex.gov.au/sites/g/files/net1896/f/files/2014/06/Improving-Energy-Efficiency-in-Barrick-GrindingCircuits.pdf.

[62] Schreiber A., Marx J., Zapp P., Hake J.-F., Voßenkaul D., Friedrich B. Environmental Impacts of Rare Earth Mining and Separation Based on Eudialyte: A New European Way. Resources 2016:5(4):32. doi:10.3390/resources5040032

[63] Sjunnesson J. Life Cycle Assessment of Concrete. Master Thesis, Lund University, 2005.

[64] Ercelebi S., Bascetin A. Optimization of shovel-truck system for surface mining. The Journal of the Southern African Institute of Mining and Metallurgy 2009:109:433-439.

[65] Dindarloo S. R., Osanloo M., Frimpong S. A stochastic simulation framework for truck and shovel selection and sizing in open pit mines. Southern African Institute Mining Metallurgy 2015:115:209-219. doi:10.17159/2411-9717/2015/v115n3a6

[66] Kittipongvises S., Chavalparit O., Sutthirat C. Greenhouse gases and energy intensity of granite rock mining operations in Thailand: A case of industrial rock-construction. Environmental and Climate Technologies 2016:18(1):64-75. doi:10.1515/rtuect-2016-0014

[67] Dubsok A., Kittipongvieses S. Estimated greenhouse gases emissions from mobile and stationary sources in the limestone and basalt rock mining in Thailand. American Journal of Environmental Sciences 2016:12(5):334-340. doi:10.3844/ajessp.2016.334.340

[68] DOE, US. Mining industry energy bandwidth study. Washington: US Department of Energy, 2007.

[69] Mudd G. M., Weng Z., Memary R., Northey S. A., Giurco D., Mohr S., Mason L. Future greenhouse gas emissions from copper mining: assessing clean energy scenarios. Cluster research 2012:1.21.

[70] Picard D. Fugitive Emissions from Oil and Natural Gas Activities. Good Practice Guidance and Uncertainty Management in National Greenhouse Gas Inventories 2006:103-127.

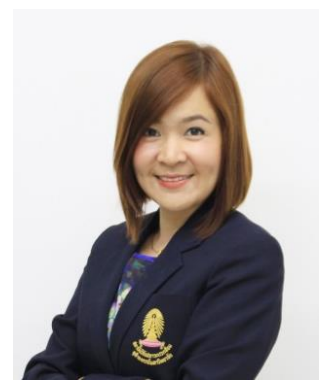

Dr. Suthirat Kittipongvises is currently a lecturer at Environmental Research Institute, Chulalongkorn University (ERIC), Thailand. She received the Ph.D. degree in Sustainability Science from the Graduate Program in Sustainability Science (GPSS), Graduate School of Frontier Sciences (GSFS), the University of Tokyo, Japan in 2013. She also earned master degree on Environmental Engineering and Management, Asian Institute of Technology (AIT), Thailand in 2008. Her research focuses on climate change mitigation, GHGs quantifications, carbon capture and storage, green mining and so on. Furthermore, she has attended and presented her research at various international conferences including International Climate Change Conference in Copenhagen, Denmark in 2009, International Conference of Climate Change and Global Warming, Venice, Italy in 2011, International Conference on Sustainability Science, Arizona, USA in 2012, International Conference on Ecology, Ecosystems and Climate Change, Athens, Greece in 2013, International Expert Dialogue on Applying Resilience Concept for Climate Change Study and Disaster Management in Thailand Context, Bangkok, Thailand in 2014, International Conference on Environmental Science and Development, Amsterdam, Netherland in 2015, International Conference on Ecosystems, Environment and Sustainable Development, Sydney, Australia and International Conference on Alternative Fuels: Future and Challenges (ICAF-2016), Kayseri, Turkey in 2016. 